\title{
Honey, I blew up the Marlboro Man
}

One of Hollywood's most successful movies of all time was "Honey, I shrunk the kids," a comedy in which a zany inventor builds a machine which inadvertently shrinks his children to the size of ants. Last summer's sequel, "Honey, I blew up the kid," involves a machine which enlarges the inventor's toddler to the height of a skyscraper. Always ahead of its time, Philip Morris has, for many years, blown up its Marlboro billboards to play havoc on the innocent people below.

One of the most offensive (and effective) billboards I've seen is a $64 \times 39$ foot $(19.5$ $\times 11.9 \mathrm{~m}$ ) "cut-out" of the Marlboro man (figure 1), situated alongside one of the busiest highways in Michigan-eastbound I-94. This artery connects downtown Detroit with the city's Metro Airport. (Detroit is the seventh

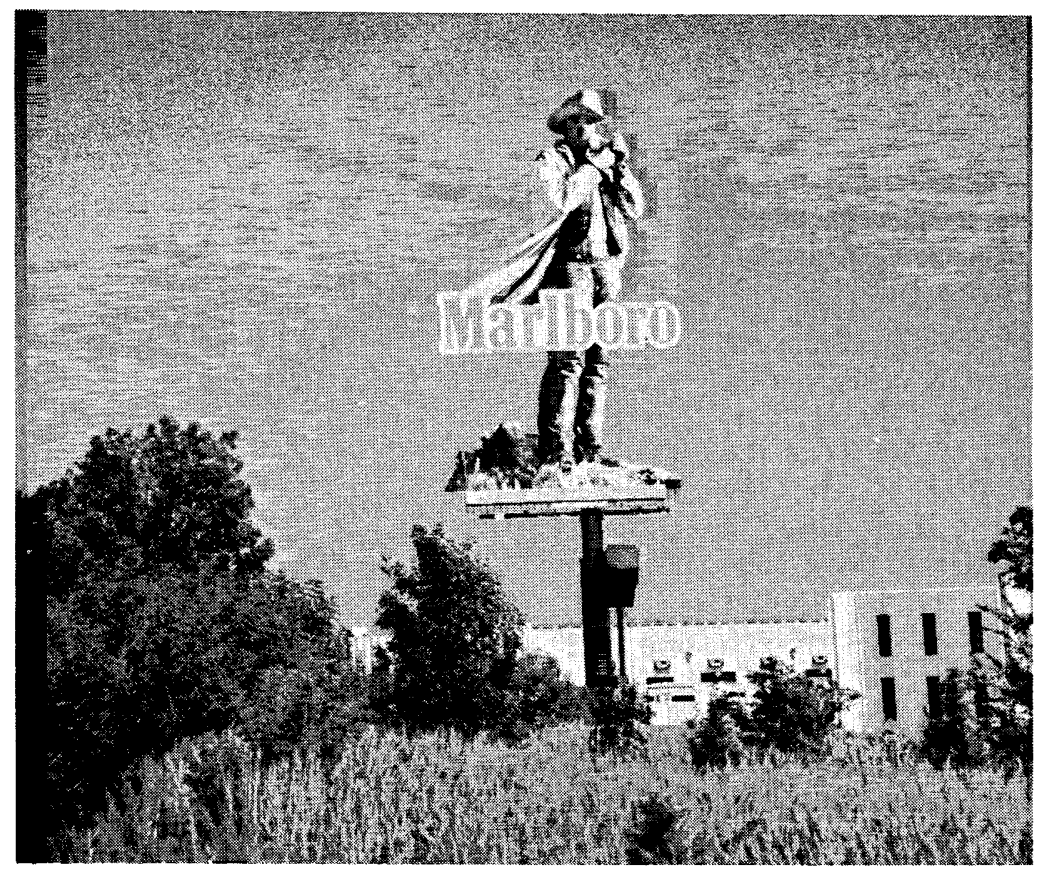

Figure 1 Alongside highway 1-94, between downtown Detroit and the Detroit Metro airport, Michigan

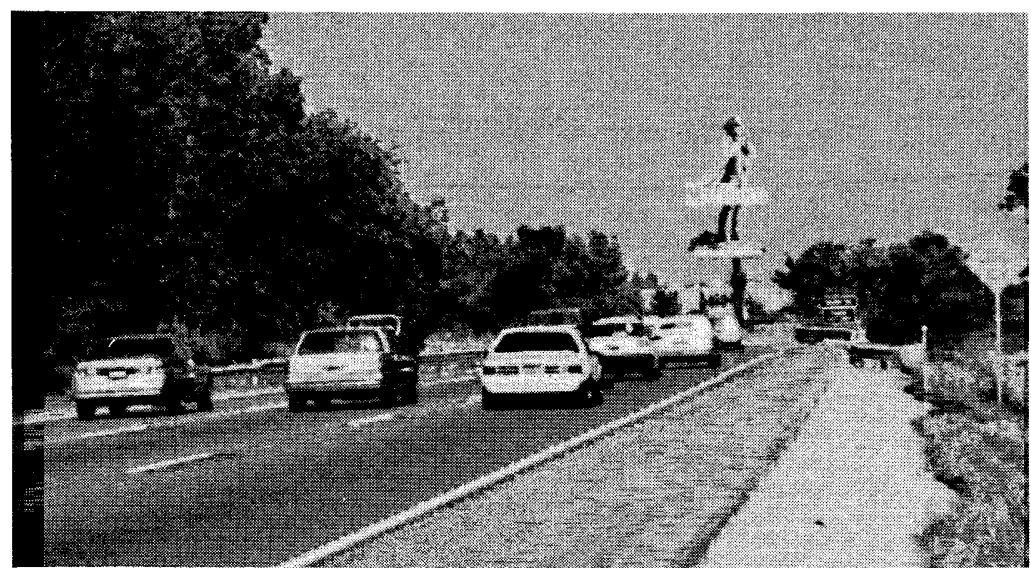

Figure 2 Alongside highway I-94, between downtown Detroit and the Detroit Metro airport, Michigan largest city in the United States, with a 1990 population of 1.0 million.) It handles 170000 drivers per day, and is one of the mostrequested billboard locations in the area. ${ }^{1}$

This Marlboro billboard is owned by the Gannett Outdoor Group, the largest outdoor advertising company in North America. (Gannett Outdoor is a subsidiary of Gannett Company Inc, the multimedia giant which publishes USA Today and 80 other daily newspapers and owns and operates 10 television and 15 radio stations in major US markets. $\left.{ }^{2}\right)$ Gannett Outdoor's Michigan office calls these cut-outs "vertaculars" (C Morgan, personal communication, 14 August 1992), which apparently is short for vertical spectaculars.

I don't know how much Philip Morris pays for this particular billboard, but billboards in general would seem to be an incredible bargain. As the local newspaper reports,

Detroit's billboards are seen by more drivers every day than boards in any other major cities except New York, Houston, Chicago, San Diego and Dallas. Yet the approximate cost to have an ad seen by as many as 170000 people a day on average runs from $\$ 2500$ to $\$ 3000$ a month-about a third of the price a regular client would pay for one day's fullpage newspaper ad. ${ }^{1}$

This Marlboro monstrosity is located at the end of a long straightaway, which puts the billboard directly in the driver's view for a long stretch of highway (figure 2). The large red Marlboro letters just above the cowboy's knees become readable about a mile $(1.6 \mathrm{~km})$ away. Thus the image is forced on the driver and passengers for up to a full minute. The visibility of the billboard is further enhanced at night, when it is illuminated by powerful lights.

Apart from the billboard described above, I've seen Marlboro man cut-outs in rural Michigan (figure 3) and on the Blackfeet Indian reservation in Browning, Montana (figure 4). Ed McMahon, former director of Scenic America (an organisation based in Washington, DC, which is fighting against "the tremendous proliferation of billboard blight which has exploded all over America"3), spotted two hypertrophic Marlboro men in Los Angeles (figures 5 and 6).

Marlboro man cut-outs are common in minor league professional baseball stadiums. For example, five of the eight teams in the Carolina advanced class A league have Marlboro man cut-outs in their stadiums. ${ }^{\star}$ One of these billboards was shown (fleetingly) in the 1988 hit movie "Bull Durham," which featured actors Kevin Costner (as a player on the tobacco-spitting Durham Bulls) and Susan Sarandon.

The Surgeon General's health warnings, 


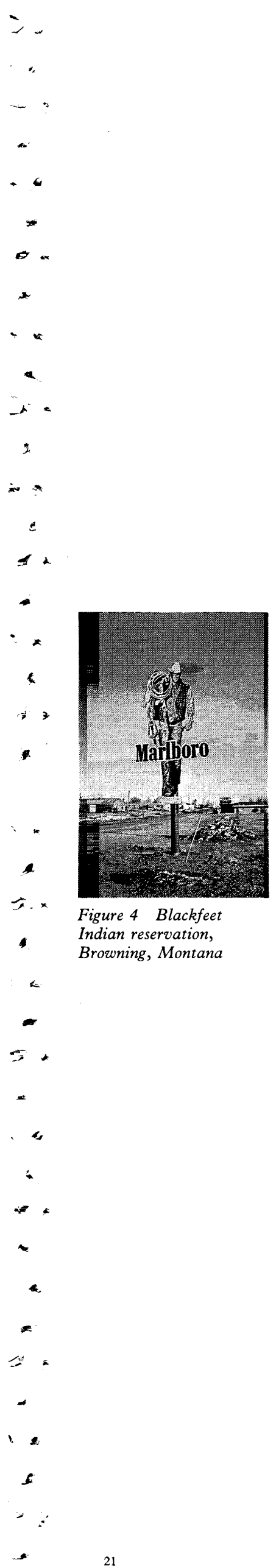

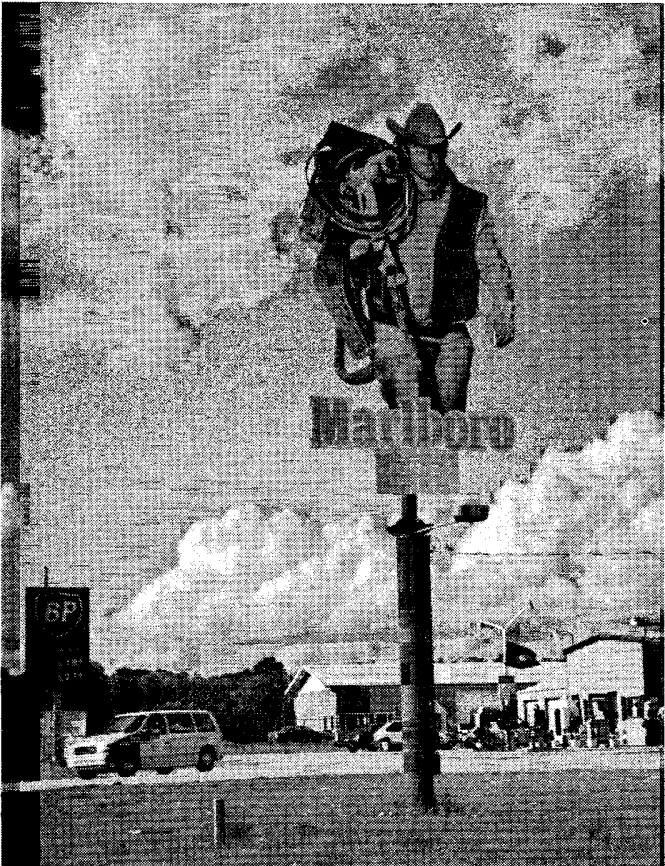

Figure 3 Marlboro man cut-out, approximately 18 feet tall (not including the steel pedestal), in rural Michigan, at the junction of highways $M-32$ and US-131

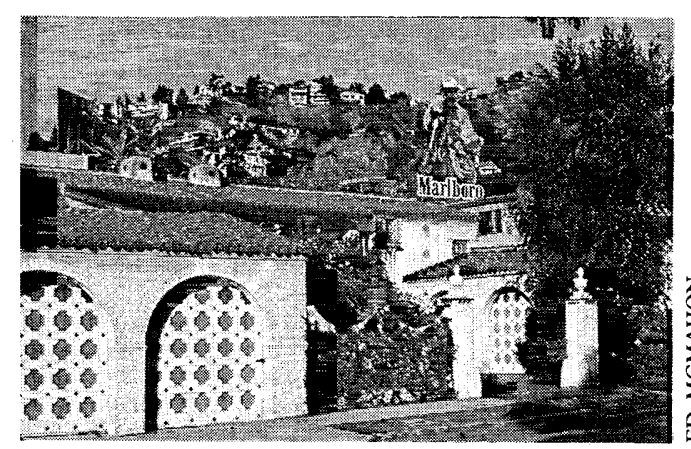

Figure 5 Los Angeles, California

which are rarely readable on conventional cigarette billboards, ${ }^{4}$ are even less visible on Marlboro man cut-outs. The height of the letters of the health warnings required on cigarette advertisements is dictated by the total surface area of an advertisement. ${ }^{4}$ By eliminating the surface area around the Marlboro man that would otherwise be present in a rectangular billboard, Philip Morris reduces the required size of the health warning.

Are Marlboro man cut-outs invading other countries? I don't know, but I was welcomed to a restaurant in the Dominican Republic by a normal-sized cut-out (figure 7). I hope readers of Tobacco Control will inform us of

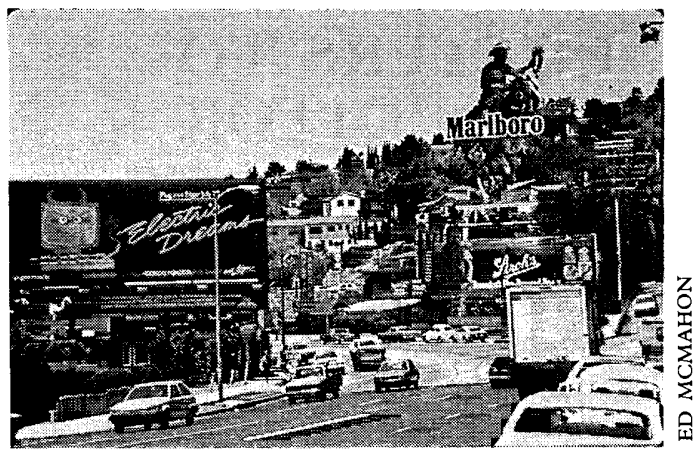

Figure 6 Los Angeles, California

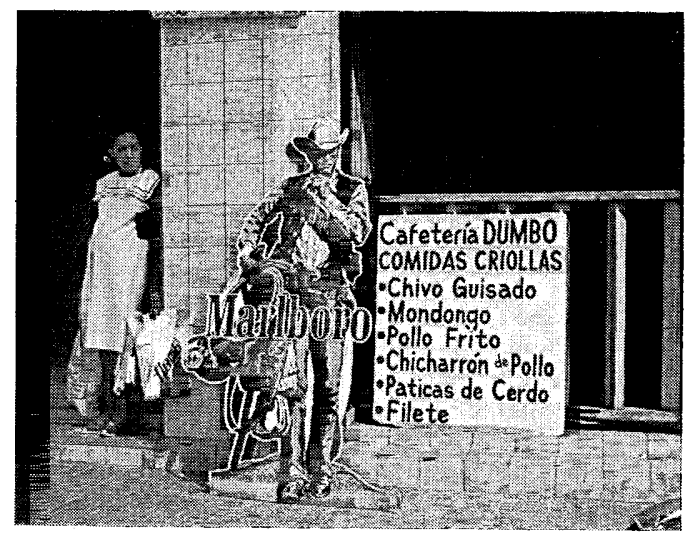

Figure 7 Cafeteria in the Dominican Republic

past or future sightings in other regions of the world.

The blown-up Marlboro man conjures up an image of David $v$ Goliath. If this beast is allowed to continue to traipse through the land, it's only a matter of time before RJ Reynolds and Brown and Williamson blow up Old Joe Camel and Kool's Willy the Penguin. ${ }^{5}$ Where's the slingshot? - ED

1 Braunstein J. Big blank states: bare billboards are the signs of tough times. Detroit News and Free Press 1992 Aug 1 : $10 \mathrm{~A}$

2 Gannett Company, Inc. Annual report 1991. Arlington, Virginia: Gannett, 1991: 3.

3 McMahon ET. Hearings before the Subcommittee on Health and the Environment, Committee on Energy and Commerce, US House of Representatives, 99th Congress, 2nd session, Serial No 99-167, fuly 18 and August 1, 1986, Washington, DC: US Government Printing Office, 1987: $772-9$

4 Davis RM. The Surgeon General's warnings in outdoor cigarette advertising: are they readable? $\mathcal{F} A M A 1989$; 261: $90-4$.

5 Tye JB. Willy the Penguin and Joe Camel duke it out for the youth market. Tobacco Control 1992; 1 : 132-3.

* Kinston (North Carolina) Indians, Salem (Virginia) Buccaneers, Peninsula (Hampton, Virginia) Pilots, Prince William (Woodbridge, Virginia) Cannons, and Lynchberg (Virginia) Red Sox. 